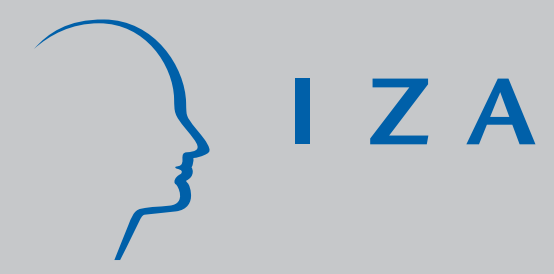

IZA DP No. 3658

The Impact of a Cash Transfer Program on

Cognitive Achievement:

The Bono de Desarrollo Humano of Ecuador

J uan Ponce

Arj un S. Bedi

August 2008 


\title{
The Impact of a Cash Transfer Program on Cognitive Achievement: The Bono de Desarrollo Humano of Ecuador
}

\author{
Juan Ponce \\ Flacso, Ecuador \\ Arjun S. Bedi \\ Institute of Social Studies, The Hague \\ and IZA \\ Discussion Paper No. 3658 \\ August 2008 \\ IZA \\ P.O. Box 7240 \\ 53072 Bonn \\ Germany \\ Phone: +49-228-3894-0 \\ Fax: +49-228-3894-180 \\ E-mail: iza@iza.org
}

Any opinions expressed here are those of the author(s) and not those of IZA. Research published in this series may include views on policy, but the institute itself takes no institutional policy positions.

The Institute for the Study of Labor (IZA) in Bonn is a local and virtual international research center and a place of communication between science, politics and business. IZA is an independent nonprofit organization supported by Deutsche Post World Net. The center is associated with the University of Bonn and offers a stimulating research environment through its international network, workshops and conferences, data service, project support, research visits and doctoral program. IZA engages in (i) original and internationally competitive research in all fields of labor economics, (ii) development of policy concepts, and (iii) dissemination of research results and concepts to the interested public.

IZA Discussion Papers often represent preliminary work and are circulated to encourage discussion. Citation of such a paper should account for its provisional character. A revised version may be available directly from the author. 
IZA Discussion Paper No. 3658

August 2008

\begin{abstract}
The Impact of a Cash Transfer Program on Cognitive Achievement: The Bono de Desarrollo Humano of Ecuador ${ }^{*}$

Throughout Latin America, conditional cash transfer (CCT) programs play an important role in social policy. These programs aim to influence the accumulation of human capital, as well as reduce poverty. In terms of educational outcomes, a number of impact evaluation studies have shown that such programs have led to an increase in school enrollment, ensured regular school attendance and led to a reduction in child labor. Theoretically, such cash transfer programs may also be expected to exert a positive impact on students' test scores, but related empirical evidence is scarce. Accordingly, this paper evaluates the impact of a cash transfer program, the Bono de Desarrollo Humano of Ecuador, on students' cognitive achievements. The paper uses a regression discontinuity strategy to identify the impact of the program on second grade cognitive achievement. Regardless of the specification and the sample used, we find that there is no impact of the program on test scores, suggesting that attempts at building human capital, as measured by cognitive achievement, require additional and alternative interventions.
\end{abstract}

JEL Classification: $\quad 138,128$

Keywords: $\quad$ cash transfers, test scores, regression discontinuity

Corresponding author:

Arjun Bedi

Institute of Social Studies

Kortenaerkade 12

2518 AX, The Hague

The Netherlands

E-mail: bedi@iss.nl

\footnotetext{
*We are grateful to Hessel Oosterbeek, Menno Pradhan, Christina Paxson, Norbert Schady, Robert Sparrow, Rob Vos and Steven Younger for comments and suggestions.
} 


\section{Introduction}

Demand-side interventions play an important role in education policy in Latin America. Broadly, two types of policies have been implemented in the region - conditional cash transfer programs (CCT) and school vouchers. As far as the former are concerned, CCT programs started during the 1990s and the main idea of these programs is to provide money to poor families, conditional on enrollment and regular attendance of their children in school and regular visits to health centers, where their growth is monitored and they receive nutritional supplements. In the long run, these programs seek to influence the accumulation of human capital, especially amongst youth and children, as a means of breaking the inter-generational cycle of poverty. In the short run, CCT programs aim to reduce poverty by increasing the income of poor families.

A number of the CCT programs operating in Latin American countries have been evaluated. While details are provided later, on the education front, a majority of the impact evaluation studies have found that CCT programs boost school enrollment and ensure regular school attendance. While these are clearly the first steps required to ensure a higher level of educational attainment and achievement, if CCT programs are to ensure that students accumulate adequate human capital to break the cycle of poverty, then a focus on enrollment is not enough. From a policy perspective it is important to examine whether such programs also lead to gains in cognitive achievement. Higher cognitive achievement as captured by test scores, are likely to ensure that a child stays in school for a longer duration (higher educational attainment) and are also correlated with labor market success. There is a limited literature on developing countries which shows that cognitive achievement increases wages and tends to have larger effects than schooling attainment. ${ }^{1}$ While the link between the level of test scores and earnings may be confounded with a number of other factors, a more recent literature focuses on gains in tests scores and earnings. For example, Jencks and Phillips (1999) show that math test scores gains between

\footnotetext{
${ }^{1}$ See Boissiere, Knight and Sabot (1985) for work on urban Kenya and Tanzania; Alderman, Behrman, Ross and Sabot (1996) for work on Pakistan; Lavy, Spratt and Leboucher (1997) for work on Morocco.
} 
$10^{\text {th }}$ and $12^{\text {th }}$ grade exert a positive impact on educational attainment and also exert a positive impact on earnings nearly a decade after students graduated from high school. Rose (2006) shows that employed women who gained one standard deviation more than average on math test scores between $8^{\text {th }}$ and $12^{\text {th }}$ grade, experience, on average, a 9 percent increase in earnings. Her results also show that for women, gains in test scores influence the probability of finding employment. ${ }^{2}$

Theoretically, such programs are likely to influence students' cognitive achievements in several ways. On the one hand, there could be a positive impact because CCT programs increase attendance rates and higher attendance is likely to lead to higher test scores. ${ }^{3}$ Cash transfer program induced increases in household incomes may be expected to lead to increased food consumption and better nutrition which in turn should translate into higher levels of cognitive achievement. Several evaluations have shown that these programs are associated with a reduction in the probability that a child works which again maybe expected to exert a positive impact on test scores. ${ }^{4}$ On the other hand, these programs may also have a negative effect on test scores. Increases in school enrollment may translate into congested classrooms, which in turn may negatively affect cognitive achievement. Whether such programs exert a positive effect on test scores or whether congestion effects dominate, leading to a reduction in learning and test scores is an empirical question.

While there are a number of studies that have examined the effect of CCT programs on enrollment, child work and other outcomes, the number of studies evaluating the effect of the CCT program on cognitive achievements is scarce. Therefore, the

\footnotetext{
${ }^{2}$ A number of authors have used developed country data to examine the impact of the level of test scores on earnings. For example, based on US data, Murnane, Willett, and Levy (1995) show that the importance of mathematics test scores in predicting earnings grew during the 1970s and 1980s. For the same time period, Bedard and Ferrall (2003) use international data to compare test scores distributions at age 13 with the distribution of subsequent wages and conclude that the trends in the two distributions are related.

${ }^{3}$ Bedi and Marshall (1999 and 2002) discuss the link between school attendance and test scores in Honduras. In particular, they report that an increase in school attendance by 5 days increases grade 2 mathematics and Spanish test scores by about 1.5 points.
}

${ }^{4}$ See Rawlings and Rubio (2003), Caldés, Coady, and Maluccio (2004) and Villatoro (2005) for reviews. 
contribution of this paper is to evaluate the impact of the Ecuadorian cash transfer program (Bono de Desarrollo Humano-BDH) on students' cognitive achievements. In particular, the paper exploits the manner in which the $B D H$ is allocated and relies on a regression discontinuity approach to identify the impact of the program on second grade cognitive achievement.

The paper is organized as follows. The next section presents a review of the main demand side interventions and their impact on educational outcomes in Latin America. The third section presents a country background and a program description. The fourth section outlines the empirical approach. The fifth section presents the data and descriptive statistics while the sixth presents the results. The final section concludes the paper.

\section{Conditional cash transfer programs in Latin America}

The first Latin American CCT program started in 1995 in Brazil under the government of the Distrito Federal of Brasilia (Bolsa Escola). Other early experiences include Mexico's Progresa (now re-named Oportunidades), which started operations in 1997. In 1998, Honduras restructured a safety net program into a CCT program (Programa de Asignacion Familiar PRAF) while Nicaragua started its CCT program in 2000 (Red de Protección Social). ${ }^{5}$

A number of studies have examined the impact of these programs on school enrollment, attendance, nutrition and child work. In particular, experimental designs have been used to examine the impact of the CCT programs in Mexico (Skoufias, 2000; Schultz, 2004; Behrman, Sengupta and Todd, 2005) and Nicaragua (Maluccio and Flores, 2004). In the case of Mexico, Schultz (2004) reports that at the primary school level, where enrolment rates before program implementation were between 90 and 94 percent, the program had a small positive impact with an increase in enrolment of between 0.8 to 1.18 percentage points for boys and 0.92 to 1.27 percentage points for girls. At the secondary level, where the initial enrolment rates were 67 percent for girls and 73 percent for boys, the program increased enrolment rates for boys by 6.2 percentage points and for girls the

\footnotetext{
5 Other countries with CCT programs include, Costa Rica (Superémonos), Colombia (Familias en Acción), Argentina (Familias por la Inclusion Social), Uruguay (Proyecto 300), Chile (Chile Solidario), Ecuador (Bono de Desarrollo Humano), and Jamaica (Programa de Avance Mediante la Saludy la Educacion).
} 
corresponding effect was 9.2 percentage points. Other program effects as reported by Skoufias (2000) include, in 1999, a 13 percent increase in median food expenditure, improvement in child health (children aged 0 to 5 years were 12 percent less likely to be ill), and reduction in child stunting. Behrman, Sengupta and Todd (2005) also report a program induced increase in enrollment as well as lower dropout and repetition rates. However, in terms of cognitive achievement, Behrman, Sengupta and Todd (2000) find that after almost a school year and a half of exposure there is no impact of the program on test scores.

In Nicaragua, Maluccio and Flores (2004) show that the CCT program increased school enrollment amongst children in the age group 7 to 13 by 18 percentage points, led to a 23 percentage point increase in attendance (during the previous month) and reduced the incidence of child work by 5 percentage points. In addition, the program led to a 5 percentage point reduction in stunting amongst children aged 0 to 5 .

Other CCT programs have been evaluated using non-experimental methods. For example, Duryea and Morrison (2004) use regression analysis and propensity score matching to evaluate Costa Rica's Superémonos program. Their propensity score estimates show that the program increased school attendance for children in the group 13 to 16 by 5 to 8.7 percentage points but did not have any effect on their work patterns. The effect of the program on school performance as measured by the probability of passing a grade indicated a 5 percentage point increase for program participants but was not robust to changes in estimation method. Attanasio et al., (2006) use propensity score matching to evaluate a CCT program (Familias en Accion) in rural Colombia. They find that the program increased school participation of 14 to 17 year old children by between 5 to 7 percentage points, and school enrolment of younger children by 1.5 to 2.5 percentage points. They also find that the program was associated with a reduction in the participation of younger children in domestic work by about 10 to 12 percentage points.

While there are differences across countries, the overall pattern emerging from the impact evaluation studies that have been conducted in Latin America is that, in general, 
CCT programs have led to substantial increases in school enrollment especially for children at the secondary school level with more modest effects at the primary level. The programs have also led to increases in school attendance and in several cases also led to reductions in child work and improvements in health outcomes (for children in the age group 0-5). The effects of such programs on measures of school performance such as test scores and the probability of passing a grade have not yet been extensively researched and the evidence that does exist does not yield clear conclusions.

\section{Country background and program description}

Ecuador is a lower-middle income country, characterized by high levels of poverty and inequality. ${ }^{6}$ Regarding education, the country has witnessed sharp improvements in the last few decades. ${ }^{7}$ For example, the average educational attainment of the population aged more than 24 years increased from 6.7 to 7.3 between 1990 and 2001. The net enrolment rate at the primary and secondary level, increased from 68.6 and 29.5, in 1982 to 88.9 and 43.1, in 1990 respectively. However, between 1990 and 2001, net enrolment rates for both primary and secondary levels stagnated and in 2001 (90.1 percent and 44.6 percent respectively) were at the level achieved in 1990. Educational achievement fell and according to information from the Ecuadorian System of Educational Achievements Measurement ("Sistema Nacional de Medición de Logros Académicos SNMLA"), test scores for mathematics and language, which are marked out of 20 , decreased from 9.7 and 10.7 to 8.5 and 9 respectively for the second grade of primary education during the second half of the 1990s. A similar deterioration was observed for students in sixth grade and for students in secondary school. Repetition and dropout rates also increased during the 1990s.

Towards the end of the 1990s, in a bid to boost school enrollment amongst the poorer segments of the population and to raise achievement the Ecuadorian government launched a conditional cash transfer program (Beca Escolar) and a school-meal program

\footnotetext{
${ }^{6}$ In 2004, per capita GDP in constant 2000 prices was US\$1,435. Based on the 2001 population census, and using the criteria of unmet basic needs, poverty was estimated to be at around 61 percent while based on the 1999, Living Standards Measurement Survey, the consumption Gini coefficient was 0.47.

${ }^{7}$ Compulsory schooling in Ecuador starts at age 5 and ends at 14 and includes one year of pre-school, six years of primary school and three years of basic secondary school.
} 
(Programa de Alimentacion Escolar). The Beca Escolar program consisted of transferring US $\$ 5$ per month per child (up to two children per household), conditional on a child being enrolled in school and maintaining a monthly attendance of 90 percent.

At about the same time (in 1998), a program ("Bono Solidario") was also launched to compensate poor families for the elimination of gas and electricity subsidies. Initially, the program used a self-targeting strategy to target mothers with monthly earnings below US\$40, people with disabilities and senior citizens. While the immediate political justification for this program was to compensate the poor for losses in their real purchasing power caused by statutory increases in (heavily subsidized) petroleum and natural gas prices, the program quickly took on a life of its own, becoming the government's largest social expenditure outside of education, with total transfers equal to about one percent of the GDP (León, Vos, and Brborich, 2001). By comparison, public education and health expenditures account for two-and-a-half and a bit less than one percent of GDP, respectively. The transfer was modest, but not trivial by Ecuadorian standards. At the time that the program started, mothers received 100,000 sucres per month, about US $\$ 15$, and senior citizens and people with disabilities received 50,000 sucres. In April 1999, those amounts were increased by 50 percent, mostly to account for high inflation. On average, the share of Bono Solidario income in total household expenditures was 11 percent in 1999. During 2000, the program reached around 1.2 million beneficiary households, representing about 45 percent of Ecuadorian households.

In 2003 the Bono Solidario was reformulated and became a CCT. The program was renamed Bono de Desarrollo Humano $(B D H)$ and incorporated both the Bono Solidario and the Beca Escolar. The main objective of the new program is to improve the formation of human capital among poor families in Ecuador. Education and health are the two components of the program. The education component requires children from the ages of 6 to 15 to enroll in school and to attend at least $90 \%$ of the school days in a month. The health component requires children under the age of six to attend health centers for bimonthly medical check- 
ups where their growth and development is monitored and they receive nutritional supplements and immunization.

To select beneficiaries, the program uses an individual targeting strategy based on a proxy-means test. In particular, program participation is based on an index called Selben, or system of selection of beneficiaries of social programs. Selben identifies potential beneficiaries of social programs by classifying households according to an unmet basic needs index computed using non-linear principal components analysis. ${ }^{8}$ Families in quintiles 1 and 2, that is, families with a Selben score of less than 50.65 are eligible to participate in the program. Beneficiaries receive a cash transfer of US\$15 per month, per family which may be compared with the average monthly expenditure of US $\$ 100$ amongst families in the target group. In 2004, the annual budget of the program was US\$190 million (around 1\% of the GDP) and the program covered about 1.1 million households or $40 \%$ of the population.

The effects of these various programs have been examined by a number of authors. For instance, Vos et al. (2001) use propensity score matching to show that Bono Solidario leads to a 5 percentage point increase in school enrolment. León and Younger (2007) use an instrumental variable approach and report that the Bono Solidario had a statistically significant but small positive effect on children's nutritional status. Turning to the $B D H$, based on an experimental evaluation design, Schady and Araujo (2006) find that the program increased school enrollment for children in the age group 6 to 17 by about 10 percentage points and reduced child work by about 17 percentage points. ${ }^{9}$ In related work, Ponce (2008) reports that households receiving the $B D H$ experience a 25 percent increase in food expenditure. Thus, consistent with the results from other programs in Latin

\footnotetext{
8 The index is scaled from 0 (poorest) to 100 (richest). More details on the construction of the Selben index are provided later on in the text.

9 Oosterbeek, Ponce and Schady (2008) use an experimental and non-experimental design to show that the enrollment effect is heterogeneous and that the increase in enrollment is restricted to children around quintile 1 (poorest families) while enrollment for children from families around quintile 2 is unaffected by the program.
} 
America, the program in Ecuador is associated with an increase in school enrollment, improvements in nutritional status and increases in food expenditure.

\section{Empirical strategy}

As discussed above, during the second half of the 1990s Ecuador recorded a decline in cognitive achievements for students in primary and secondary school. The $B D H$ was a response to this decline and has the stated aim of increasing human capital formation amongst poor families in Ecuador in order to break the inter-generational cycle of poverty. While there is ample evidence that CCT programs such as the $B D H$ have been successful at raising enrollment and attendance as well as in some cases reducing child work and improving nutritional status of children, whether such outcomes also translate into higher levels of learning as measured by gains in test scores is not clear. Given the link between gains in test scores and subsequent labor market outcomes, if CCT programs are to meet their stated aims it is important to focus not just on enrollment and attendance but also on learning.

To isolate the effect of the program on students' test scores, we begin with the following educational production function:

$$
Y_{i}=X_{i} \beta+f\left(S_{i}\right)+\alpha T_{i}+u_{i}
$$

where $Y_{i}$ is the outcome variable (test scores), $T_{i}$ is an indicator variable that equals 1 if a child lives in a family receiving the $B D H$ and 0 otherwise, $X_{i}$ is a vector of individual, household, school and teacher characteristics, $f\left(S_{j}\right)$ is a flexible function (a third degree polynomial) of the Selben $\left(S_{i}\right)$ index and $u_{i}$ is an unobserved error term. ${ }^{10}$ Since program participation is not random and purposively targets the poor, it is likely that $T_{i}$ is negatively correlated with the error term $u_{i}$, and OLS estimates of $\alpha$, the main parameter of interest, are likely to be downward biased.

\footnotetext{
${ }^{10}$ A potential pitfall of the RD approach is that it assumes that the relationship between the outcome variable and the variable that determines treatment is known. If one assumes the wrong functional form, estimates can be biased because of model misspecification. If, for example, the relationship is non-linear around the cutoff, but the function is specified as linear, then the estimated treatment effect may simply pick up any underlying non-linearity in the function (see Jacob and Lefgren 2004; Chay, McEwan and Urquiola 2005). To deal with this problem we use a third degree polynomial of the Selben index.
} 
To tackle this problem, we exploit the BDH's targeting mechanism and rely on a regression discontinuity $(\mathrm{RD})$ strategy to isolate the causal effect of the program. ${ }^{11}$ As stated earlier, program participation is based on the Selben index and is intended only for families scoring below $50.65\left(S_{0}\right)$. In other words, assignment to the program depends on the value of an observed continuous variable (Selben) relative to a given cutoff point. This mechanism generates a highly non-linear relationship between treatment status and the Selben index. Figure 1 illustrates this relationship and shows that as the Selben index declines there is an increase in the probability of being treated but there is sharp spike at the cutoff point of 50.65. Households with a Selben index of less than 50.65 are about 10 percentage points more likely to be in the treatment group as compared with households that have a Selben index of just above 50.65. As illustrated in the figure, the non-linear relationship between the Selben index and treatment status provides exogenous variation in treatment status which may be used to identify the causal effect of the program.

If individuals were assigned to treatment solely on the basis of the assignment variable, that is, all those above the cutoff point $\left(S_{\diamond}\right)$ do not receive the treatment $\left(T_{i}=0\right.$ if $S_{i}$ $\left.>S_{0}\right)$, whereas all those who lie below do $\left(T_{i}=1\right.$ if $\left.S_{i} \leq S_{0}\right)$ then $T$ would be deterministic and would depend only on the score in the Selben index. Under such circumstances ("sharp" discontinuity design), assuming that unobserved characteristics vary continuously around the cutoff with the observable characteristics used to determine treatment, the program allocation rule replicates random assignment of individuals to treatment status around the cutoff point. Accordingly, individuals lying within an arbitrarily small interval above and below the cutoff point are likely to have similar observed and unobserved characteristics and, restricting the sample to those just below and just above the cutoff and

\footnotetext{
11 The regression discontinuity approach proposed here has often been used to evaluate the effects of educational interventions. Examples of such studies include, Thistlethwaite and Campbell (1960), Black (1999), Angrist and Lavy (1999), Hahn, Todd and Van der Klaauw (1999), Van der Klaauw (2002), Jacob and Lefgren (2004).
} 
comparing test scores of children on either side of the cutoff is likely to yield unbiased program effects. $^{12}$

Identifying program impact based on restricted sample OLS estimates assumes that program participation is a deterministic function of the assignment rule. However, this is unlikely and as shown in Table 1 there is a fair degree of "fuzziness" in program assignment. For about 66 percent of the sample (1721/2595) eligibility and program status match, but there are 673 individuals (26 percent) who are eligible but do not receive the program and 201 individuals ( 8 percent) who are not eligible but do receive the program. ${ }^{13}$ Thus, assignment to treatment status depends on the Selben index in a stochastic manner. To estimate the treatment effect in the presence of fuzzy discontinuity, following Hahn et al. (2001), we adopt an IV approach. Program participation, or the first stage equation, is treated as a function of an instrument $(Z)$, the Selben index $(S)$ and other variables $(X)$. The instrument $(Z)$ is based on the decision rule and takes the value of 1 for those scoring below the cutoff in the Selben index (50.65) and the value of 0 for those scoring above the cutoff. This first stage equation may be written as:

$$
T_{i}=X_{i} \delta+f\left(S_{i}\right)+\gamma Z_{i}+w_{i}
$$

Since the instrument is based on the assignment rule it is likely to be highly correlated with program participation (see Figure 1). However, we also need to assume that unobserved characteristics that determine student test performance are not correlated with the instrument, that is, we assume, $E\left(Z_{i} \cdot u_{i} \mid X_{i}, S_{i}\right)=0$. If this assumption holds then consistent program estimates may be obtained by estimating,

$$
Y_{i}=X_{i} \beta+f\left(S_{i}\right)+\alpha \hat{T}_{i}+u_{i}
$$

\footnotetext{
12 That is, OLS estimates of an equation such as $Y_{i}^{R S}=X_{i}^{R S} \beta_{r s}+\delta_{r s} S_{i}+\alpha_{r s} T_{i}^{R S}+u_{i}$, where $R S$ indicates arbitrarily restricted samples above and below the cutoff point is likely to yield unbiased estimates of the program.

${ }^{13}$ Leakage occurs mainly because some households who received benefits under earlier intitiatives continued to receive benefits through the $B D H$ program, although based on the Selben index they were no longer eligible. On the other hand eligible households who did not participate in village-level meetings at the time that the Selben was originally being calcuated, although eligible, do not receive the $B D H$.
} 
where $\hat{T}$ is obtained from (2). ${ }^{14}$ Estimates based on (3) provide the average treatment effect for those around the discontinuity point, that is, it is the treatment effect for those whose participation has been influenced by the assignment rule (instrument). This effect is usually termed the local average treatment effect.

\section{IV.2 Reproducing the Selben index}

The implementation of the $\mathrm{RD}$ design is based on the idea that the researcher has information on the Selben index and therefore on program eligibility. However, while the post-program data that we have has information on outcomes and several other characteristics and we know whether families are program participants or not we do not know each families score in the Selben index and nor do we have information in the postprogram data on characteristics at the time that the Selben index was actually developed and used to determine program participation. Thus, in order to implement the RD strategy and replicate the assignment process the first step is to reproduce the Selben index using the post-program data.

The original Selben index was constructed using non-linear principal components analysis and a combination of 27 variables. These variables can be classified into the following groups: infrastructure (6 variables), demographic characteristics of household members ( 9 variables), educational characteristics of household members (4 variables), and household assets (8 variables). The index is scaled from 0 to 100 . As already mentioned, families scoring below 50.65 were eligible to receive the benefit, while families scoring above 50.65 were ineligible. While the Selben is constructed using 27 variables, the postprogram data that we have has information on only 20 of the 27 variables.

For the construction of the original version of the index, researchers from the Technical Secretariat of the Social Cabinet used the 1999 Living Standards Measurement Survey (LSMS). The various categories and variables used as well as their respective weights

\footnotetext{
14 This assumption may not hold if individuals can influence their position relative to the cutoff (Jacob and Lefgren, 2004). In our case, this should not be a problem as families do not have any control over the calculation of the Selben index and nor are they aware of the scoring procedure.
} 
can be seen in Table A1. To replicate the index, we worked with the same survey (LSMS 1999) using only the 20 variables available in our post-program data. Using the same statistical procedure (non-linear principal components), we re-estimated the index to obtain the new weights for the restricted set of 20 variables and created a quasi-selben index. The variables used as well as their respective weights can also be seen in Table A1. A regression of the Selben index on the quasi-selben index shows that the original Selben index can be computed based on the quasi-selben index on the basis of the following equation:

$$
\text { Selben }=9.159029+0.925 * \text { quasi_selben }
$$

$$
\text { (0.14312) (0.0032) }
$$

Standard errors are in parentheses. The R-squared of the regression is 0.93 .

Finally, with the new weights for the restricted set of 20 variables and using the post-program data we computed the quasi-selben index, while equation (4) was used to obtain the Selben index for each family in the post-program data set.

\section{Data}

The data used in this paper were gathered between November 2004 and February 2005, which is about a year and a half after the launch of the BDH program, by the Latin America Faculty of Social Sciences (Facultad Latinoamericana de Ciencias Sociales, FLACSOEcuador). The fieldwork to gather data was very intensive and covered the rural areas of the country and the capital Quito and utilized three different instruments. Standardized tests in mathematics and language were conducted to gather information on cognitive achievement from students in second and fourth grades and for each child the research team obtained information on school and teacher's characteristics and household variables. ${ }^{15}$ The test scores, as well as school and teacher questionnaires, were filled out in the school, while the household questionnaire was filled out at the child's home.

\footnotetext{
15 This paper present results only for the second grade. The results for the fourth grade are similar and are available on request.
} 
The second grade sample includes 2,588 children (1,469 in the treatment and 1,119 in the control group). The school questionnaire contains information on school infrastructure, the number of teachers, the number of students, the number of classrooms, availability of books, computers and other school inputs. The teacher questionnaire was applied to the teachers in charge of mathematics and language and the survey obtained information on the teacher's education, experience, the type of contract (hired by the Ministry of Education or by the school), and the number of training courses attended during the last four years.

The household questionnaire contains information on household assets and infrastructure. At an individual level, the survey contains information on parental education levels, marital status and language spoken by household members. In addition, employment status, labor conditions and information on income for all those aged above 5 is gathered. For children between 5 to 17 years old, information on school enrolment, the type of school in which a child is enrolled and information on education spending is available. Finally, the questionnaire contains information on child's use of time and record the number of hours the child works, helps in housework, watches television and whether he or she receives some parental help for homework.

Table 1 presents selected descriptive statistics based on the complete sample, conditional on beneficiary status. As the table shows, there are substantial differences between beneficiaries and non-beneficiaries. Beneficiaries have lower test scores (about 10 percent lower) in mathematics and language and live in families with less educated heads of household. Regarding school characteristics, the percentage of children enrolled in schools with just one teacher, in schools belonging to the indigenous system and the percentage of children attending schools with a part-time principal, is higher amongst beneficiaries as compared to non-beneficiaries. ${ }^{16}$ While there are no statistically significant differences in

\footnotetext{
16 The Ecuadorian schooling system consists of two independent components - the Indigenous system, and the Hispanic system. Most indigenous students are enrolled in indigenous schools, where Quechua and Spanish are taught. Schools with one teacher are generally located in the poorer areas of the country. A fulltime principal implies that the principal takes care of administrative issues and has no teaching responsibilities.
} 
terms of access to books and learning guides, there are differences in favor of nonbeneficiaries in terms of access to computers and the internet and school infrastructure. ${ }^{17}$ Turning to teacher characteristics, once again, non-beneficiaries are more likely to be taught by teachers with a superior level of education, as well as by teachers contracted by the Ministry of Education. ${ }^{18}$

To summarize, based on these descriptive statistics, it is clear that children living in non-beneficiary families have higher cognitive achievements, they belong to families with a higher socioeconomic status, and attend better schools, as compared to beneficiaries. These differences are consistent with the targeting strategy of the program and suggest that a simple comparison of test scores between beneficiaries and non-beneficiaries is unlikely to yield credible program estimates and that, as in the regression discontinuity approach proposed here, credible program estimates are likely to be obtained only after controlling for differences in observable (including a flexible function of the Selben index) and unobservable characteristics between program beneficiaries and non-beneficiaries.

\section{Estimates}

Table 3 displays OLS estimates of the effect of the $B D H$ program on tests scores. The table contains four specifications. Specification 1 includes child characteristics (sex, age and a third-degree polynomial of the Selben index). ${ }^{19}$ Specification 2 includes, in addition, household variables indicating whether the head of household is illiterate, indigenous, and female, as well as a set of variables that captures household composition (including the number of individuals in the household in different age groups). Specification 3 expands

\footnotetext{
17 This index is scaled from 0 to 5 , and was computed using indicator variables that take the value of 1 , if a characteristic is present and 0 otherwise. The index is based on access to teacher housing, potable water, electricity, bathrooms and playgrounds.

18 Teachers in Ecuador can be hired by the Ministry of Education (the majority), or by the community and the parents and teachers associations. Teachers with contract from the Ministry enjoy better employment conditions.

${ }^{19}$ Other child variables available in the data such as the time spent on work, time spent on homework, the time spent watching TV and the amount of time parents spend with their children are not included in the specification due to endogeneity concerns. However, estimates of the coefficient on $T$ are robust to the inclusion of these variables.
} 
the specification and includes school characteristics that may have a bearing on cognitive achievements (indicator variables for urban, enrollment in a Hispanic school, enrollment in a school with one teacher or a multi-grade school, whether the school has a full time principal, access to computers, access to the internet, and the number of textbooks and learning guides per student), as well as characteristics of the teacher instructing children in mathematics and language (age, sex, education level and training, and type of contract). Finally, specification 4 includes canton fixed effects. While we present estimates based on all four specifications, for the most part we focus our attention on the estimates based on the most complete specification (that is, specification 4).

As shown in Table 1, on average (unconditional mean), non-beneficiaries have about a one point advantage over program beneficiaries in Mathematics and language test scores. The various estimates in Table 3 suggest that a large part of this gap in the case of mathematics and almost the entire gap in the case of language may be attributed to differences in observable characteristics. Moving along the table from left to right, there is a decline in the test score advantage for beneficiaries. However, despite this decline, based on the estimates in Table 4-specification 4, prima facie it appears that program participation is associated with a reduction in mathematics tests scores of about one-third of a point while there is no effect of program participation on language test scores.

\section{IV estimates}

While the preceding OLS estimates control for a variety of observed characteristics, as argued earlier, they do not control for endogeneity of program participation. To control for this we exploit the program's allocation mechanism and create an instrument which allows us to obtain IV estimates of the effect of the program on test scores. First stage estimates of program participation using program eligibility as an instrument (equation 2), are provided in Table 5. Across the four specifications there is a clear effect of eligibility on program participation. Consistent with figure 1, regardless of the specification, program eligibility is associated with a 10-11 percentage point increase in the probability of receiving the program. The coefficient is statistically significant with F-statistics ranging from 4.7 to 
5.3 displaying the clear effect of eligibility status on program participation. While it is clear that (around the cutoff point) the instrument increases the probability of program participation, is it likely that the instrument is not correlated with the error term in the test score equation? As discussed above, the instrument is a non-linear function of the Selben index and identifying information comes from the non-linearity imposed by the program design. Given this structure, there seems to be little reason to expect why, after controlling for observable characteristics and a flexible functional form of the Selben index, an arbitrarily imposed cut-off point (over which families have no control) in the Selben index would be correlated with unobserved characteristics that determine test scores.

IV estimates of the effect of $B D H$ on test scores are provided in Table 5. At first glance these estimates look implausibly large, positive and statistically significant. However, estimates based on the most comprehensive specification (Table 5-specification 4) display that for both mathematics and language the effect of the program on test scores is statistically insignificant. Although, insignificant, as compared to the OLS estimates, the IV estimates indicate that there is a positive relationship between program participation and test scores or put somewhat differently, there seems to be no evidence that program participation has a negative effect on test scores, for example, due to congestion effects. The larger IV estimates also suggest that there is a negative correlation between the errors in the test scores and program participation equation and that in the absence of controls for differences in unobserved characteristics between program beneficiaries and nonbeneficiaries, there would be a tendency to underestimate the impact of the program on test scores.

While the IV estimates are not statistically significant, their size warrants additional discussion. The IV estimate of the program on test scores is the ratio of the differences in average test scores and increase in the probability of participation (controlling for other variables) between individuals whose participation has been influenced by the assignment 
rule (instrument) and those unaffected by the assignment rule. ${ }^{20}$ The IV estimate depends on the marginal effect of the program on the group whose probability of participation is affected by the assignment rule. If the assignment rule affects a group with a high marginal return from the program then the IV estimate, which is the average treatment effect for those affected by the assignment rule, may be quite large. In this case the large size of the IV estimate suggests that the group of individuals who are around the cutoff point experience a large increase in test scores, although the effect is not precise.

Although not reported in the paper we experimented with limiting the sample to individuals around the cutoff point $( \pm 1,2,3$ points around the cutoff), with a linear specification of the Selben index, and with samples of children in grade 4. Regardless of these changes, we were unable to reject the hypothesis that the program has no impact on test scores.

\section{Intention-to-treat estimates}

The IV estimates show that there is no positive and statistically significant effect of the program on test scores. However, the IV estimates are local average treatment effects and do not rule out the possibility that the program effect is heterogeneous and may have an impact on test scores for individuals at lower percentiles of the Selben distribution. While we cannot provide average treatment effects on the treated we can provide an idea of the average potential effect of the program.

Given the program assignment mechanism and based on the assumption that eligibility, controlling for observables and a flexible function of the Selben index is uncorrelated with the error term $(u)$, a regression of test scores on program eligibility (reduced form estimates of the test scores equation) yields the "intention-to treat (ITT)" effect. While interest usually centers on the average effect of treatment on the treated, in the current context the ITT estimates are clearly policy relevant.

\footnotetext{
20 The IV estimate of the program on test scores is the ratio of the reduced form coefficients on $T$ in the test scores and participation equations. That is, using the estimates displayed in Tables 4 and 6 (specification 4), we have for mathematics, $4.899=0.486 / 0.097$ and for language, $0.402=0.039 / 0.097$.
} 
From a policy perspective it would be useful to know whether the limited effect of the program on test scores is due to the mismatch between eligibility and program receipt or whether, even if the program had been allocated as envisaged there would have been no effect of the program on test scores. The ITT estimates displayed in Table 6 provide an idea of the (minimum) average potential effect of the program on test scores had the program been allocated as envisaged. The estimates based on specification 4 show that potentially, the program exerts a positive effect on test scores. The gains are likely to be larger for mathematics than for language but even if allocated correctly, it appears that gains in test scores are not likely to be large enough to be statistically significant at conventional levels. For example, even for mathematics, the estimates (Table 6, specification 4) show that an increase in test scores of up to 0.8 points out of 20 can be excluded with 95 percent probability as a potential impact estimate.

\section{Concluding remarks}

Throughout Latin America, CCT programs play an important role in social policy. These programs aim to reduce poverty and to promote accumulation of human capital. On the educational front, several papers have shown the substantial impact of these programs on boosting school enrollment and ensuring regular school attendance. While these are clearly the first steps to enhance educational attainment, if the aim of these programs is to build human capital and break the cycle of poverty then a focus beyond enrollment, on learning and gains in cognitive skills may also be required. While there is a considerable body of work on the effect of CCT on enrollment and attendance, their effects on learning as measured by effects on test scores has not been as extensively examined.

This paper contributed to the body of work on the impact of cash transfer programs by using information from Ecuador and by focusing on the effect of the program on test scores. We exploited the program's design and used an arguably credible empirical strategy to show that the $B D H$ does not have a positive impact on test scores. Given the fairly large mismatch between eligibility and program receipt we also examined the potential effect of the program if it had been correctly allocated. The intention to treat 
estimates suggested that even if the program had been correctly allocated, it is unlikely that the program would have led to an increase in test scores.

We analyze the effect of the program on test scores a year and a half into the program and it is possible that these conclusions are premature and going forward, the program may well exert a positive effect on learning. Alternatively, nutritional interventions through the $B D H$ program for children in the age group 0-5 (children who are not yet in school) may lead to increases in learning. These effects have yet to be evaluated.

While there is no positive impact of the program on test scores, the estimates show that despite the sharp increase in enrollment, there are at least no negative test score effects associated with the program. Nevertheless, the results reported here suggest that while demand side interventions to get children to enroll and attend school are successful, boosting learning may require alternative and additional programs. Rather than focusing only on getting children to come to school, programs that also consider the supply side, for example, getting teachers to come to school may have a larger bearing on boosting learning than demand-oriented cash transfer programs. ${ }^{21}$

${ }^{21}$ For example, a recent report based on a nationally representative teacher tracking survey conducted in Ecuador in 2002, reports a teacher absenteeism rate of 14 percent (see http://siteresources.worldbank.org/DEC/Resources/37912_Ecuador.Teacher.Absenteeism.August13.2004. pdf, accessed on July 21, 2008. On a related note, Bedi and Marshall (2002) use data from Honduras to show that at least 60 percent of the schools days missed by a child during a school year may be attributed to the lack of supply of schooling. 


\section{References}

Alderman, H., Behrman, J., Ross, D. and Sabot, R. (1996). The returns to endogenous human capital in Pakistan's rural wage labour market. Oxford Bulletin of Economics and Statistics, 58 (1), 29-55.

Angrist, J, and Lavy, V., (1999). Using Maimonides rule to estimate the effect of class size on scholastic achievement. Quarterly Journal of Economics 114 (2), 533 -575.

Attanasio, O., Fitzsimons, E., López, D., Meghir C., and Mesnard, A. (2006) Child Education and Work Choices in the Presence of a Conditional Cash Transfer Programme in Rural Colombia. The Institute for Fiscal Studies Working Paper 06/01.

Bedard, K., \& Ferrall, C. (2003). Wage and test score dispersion: Some international evidence. Economics of Education Review, 22(1), 31-43.

Bedi, A., and Marshall, J. (2002) Primary school attendance in Honduras. Journal of Development Economics 69 (1), 129-153.

Bedi, A., and Marshall, J. (1999) School attendance and student achievement: Evidence from Rural Honduras. Economic Development and Cultural Change 47 (3), 657-682.

Behrman, J.R., Sengupta, P., and Todd, P. (2000). The impact of Progresa on achievement test scores in the first year. Washington D.C., IFPRI.

Behrman, J.R., Sengupta, P., Todd, P. (2005). Progressing through PROGRESA: An impact assessment of a school subsidy experiment in Rural Mexico. Economic Development and Cultural Change

Black, S.E. (1999). Do better schools matter? Parental valuation of elementary education. Quarterly Journal of Economics, 114(2), 577-599.

Boissiere, M., Knight J.B. and Sabot R., (1985). Earnings, schooling, ability and cognitive skills. American Economic Review 75(5), 1016-1030.

Caldés, N., Coady, D., Maluccio, J.A. (2004). The cost of poverty alleviation transfer programs: A comparative analysis of three programs in Latin America. Washington D.C., IFPRI

Chay, K.Y., McEwan, P. J., and Urquiola, M. (2005). The central role of noise in evaluating interventions that use test scores to rank schools. Mimeo.

Duryea, S., and Morrison, A. (2004). The effect of conditional transfers on school performance and child labor: Evidence from an ex-post impact evaluation in Costa Rica. Washington D.C.: Inter-American Development Bank.

Hahn, J., Todd, P., and van der Klaauw, W. (1999). Evaluating the Effect of an Andiscrimination Law Using a Regression-Discontinuity Design. National Bureau of Economic Researh. Working Paper 7131. 
Hahn, J., Todd, P., and van der Klaauw, W. (2001). Identification and estimation of treatment effects with a regression-discontinuity design. Econometrica 69(1), 201209.

Jacob, B.A. and Lefgren, L. (2004). The impact of teacher training on student achievement: Quasi-experimental evidence from school reform efforts in Chicago. Journal of Human Resources 39 (1), 50-79.

Jencks, C. and Phillips, M. (1999). Aptitude or achievement: Why do test scores predict educational attainment and earnings? In S.E. Mayer, \& P.E. Peterson (Eds.) Earning and learning: How schools matter (pp. 15-47). Washington DC: Brookings Institution Press.

León, M. and Younger, S. (2007). Transfer payments, mother's income, and child health in Ecuador. Journal of Development Studies 43 (6), 1126-1143.

Lavy, V., Spratt J., and Leboucher, N. (1997). Patterns of incidence and change in Moroccan literacy. Comparative Education Review 41 (2), 120-141.

Maluccio, J.A., and Flores, R. (2004). Impact evaluation of a conditional cash transfer program: The Nicaraguan Red de Protección Social." FCND Discussion paper No. 184.

Murnane, R.J., Willett, J.B., \& Levy, F. (1995). The growing importance of cognitive skills in wage determination. The Review of Economics and Statistics, 77(2), 251-266.

Oosterbeek H., J. Ponce, and N. Schady. (2008). The Impact of cash transfers on school enrolment: Evidence from Ecuador. World Bank, Policy Research Working Paper No. 4645.

Ponce J. (2008). Education Policy and Performance. Evaluating the Impact of Targeted Education Programs in Ecuador. Maastricht: Shaker Publishing.

Rawlings, L.B., and Rubio, G.M. (2003). Evaluating the impact of conditional cash transfer programs: Lesson from Latin America. World Bank, Policy Research Working Paper No. 3119 .

Rose, H. (2006). Do gains in test scores explain labor market outcomes? Economics of Education Review, 25 (4), 430-446.

Schady, N., and Araujo, M.A. (2006). Cash transfers, conditions, school enrolment, and child work: Evidence from a randomized experiment in Ecuador. World Bank, Policy Research Working Paper No. 3930.

Schultz, T.P., (2004). School subsidies for the poor: evaluating the Mexican Progresa poverty program. Journal of Development Economics. 74 (1), 199-250.

Skoufias, E. (2000). Is Progresa working? Summary of results of an Evaluation by IFPRI. Washington D.C.: IFPRI.

Thistlethwaite, D. and Campbell, D. (1960). Regression-discontinuity analysis: An alternative to the ex-post facto evaluation. Journal of Education Psychology 51, 309-317.

Van der Klaauw, W. (2002). Estimating the effect of financial aid offer on college Enrolment: A regression-discontinuity approach. International Economic Review 43 (4), pp. 1249-1287. 
Villatoro, P. (2005). Los Nuevos Programas de Protección Social Asistencial en América Latina y el Caribe." CEPAL. Mimeo.

Vos R. , León M., and Brborich W. (2001). Are cash transfer programs effective to reduce poverty? Mimeo. 
Table 1

Cross tabulation between assignment rule and treatment status

\begin{tabular}{|l|c|c|c|}
\hline & \multicolumn{3}{|c|}{ Selben score } \\
\hline Treatment status & More than 50.65 & Less than 50.65 & Total \\
\hline \hline Non-beneficiaries & 450 & 673 & 1,123 \\
Beneficiaries & 201 & 1,271 & 1,472 \\
Total & 651 & 1,944 & 2,595 \\
\hline
\end{tabular}


Table 2

Descriptive statistics for selected variables, Full Sample

\begin{tabular}{|c|c|c|c|}
\hline Child and Household Characteristics & $\begin{array}{c}\text { Non- } \\
\text { beneficiaries }\end{array}$ & Beneficiaries & Difference \\
\hline Mathematics, second grade (out of 20) & $\begin{array}{c}9.3761 \\
(0.1513)\end{array}$ & $\begin{array}{c}8.5102 \\
(0.1349)\end{array}$ & $\begin{array}{l}0.8659 * \\
(0.2033)\end{array}$ \\
\hline Language, second grade (out of 20 ) & $\begin{array}{l}11.1463 \\
(9.1411)\end{array}$ & $\begin{array}{l}10.2329 \\
(0.1238)\end{array}$ & $\begin{array}{l}0.9133^{*} \\
(0.1879)\end{array}$ \\
\hline Score in Selben index & $\begin{array}{l}44.1959 \\
(0.4288)\end{array}$ & $\begin{array}{l}36.5307 \\
(0.3074)\end{array}$ & $\begin{array}{l}7.6652 * \\
(0.5141)\end{array}$ \\
\hline Dummy sex $(1=$ female $)$ & $\begin{array}{c}0.4930 \\
(0.0148)\end{array}$ & $\begin{array}{c}0.4808 \\
(0.0129)\end{array}$ & $\begin{array}{c}0.0121 \\
(0.0197)\end{array}$ \\
\hline Head of the household is indigenous & $\begin{array}{c}0.3575 \\
(0.0142)\end{array}$ & $\begin{array}{c}0.5655 \\
(0.0129)\end{array}$ & $\begin{array}{c}-0.2081^{*} \\
(0.0193)\end{array}$ \\
\hline Head of the household is illiterate & $\begin{array}{c}0.1283 \\
(0.0099)\end{array}$ & $\begin{array}{c}0.1771 \\
(0.0099)\end{array}$ & $\begin{array}{l}-0.0488^{*} \\
(0.0143)\end{array}$ \\
\hline Head of the household is female & $\begin{array}{c}0.1306 \\
(0.01001)\end{array}$ & $\begin{array}{c}0.1284 \\
(0.0087)\end{array}$ & $\begin{array}{c}0.0022 \\
(0.0133)\end{array}$ \\
\hline Number of persons aged less than 6 in household & $\begin{array}{c}1.1377 \\
(0.0469)\end{array}$ & $\begin{array}{c}1.4082 \\
(0.0432)\end{array}$ & $\begin{array}{l}-0.2705^{*} \\
(0.0643)\end{array}$ \\
\hline Number of persons aged 6 to 17 in household & $\begin{array}{r}3.7702 \\
(0.0941)\end{array}$ & $\begin{array}{r}4.3773 \\
(0.0865)\end{array}$ & $\begin{array}{l}-0.6070^{*} \\
(0.1286)\end{array}$ \\
\hline \multicolumn{4}{|l|}{ School characteristics } \\
\hline Percentage of children attending schools with one teacher & $\begin{array}{c}0.1368 \\
(0.0102)\end{array}$ & $\begin{array}{c}0.1944 \\
(0.0103)\end{array}$ & $\begin{array}{l}-0.0575^{*} \\
(0.0147)\end{array}$ \\
\hline Percentage of children attending Hispanic schools & $\begin{array}{c}0.7096 \\
(0.0135)\end{array}$ & $\begin{array}{c}0.5810 \\
(0.0128)\end{array}$ & $\begin{array}{l}0.1286^{*} \\
(0.0188)\end{array}$ \\
\hline Percentage of children residing in Quito & $\begin{array}{c}0.2474 \\
(0.0128)\end{array}$ & $\begin{array}{c}0.1009 \\
(0.0078)\end{array}$ & $\begin{array}{l}0.1465^{*} \\
(0.0143)\end{array}$ \\
\hline $\begin{array}{l}\text { Percentage of children attending schools with full-time } \\
\text { principal }\end{array}$ & $\begin{array}{c}0.2360 \\
(0.0126)\end{array}$ & $\begin{array}{c}0.1022 \\
(0.0079)\end{array}$ & $\begin{array}{l}0.1337^{*} \\
(0.0142)\end{array}$ \\
\hline Number of learning guides per child & $\begin{array}{c}0.0589 \\
(0.0065)\end{array}$ & $\begin{array}{c}0.0568 \\
(0.0052)\end{array}$ & $\begin{array}{r}0.0022 \\
(0.0082)\end{array}$ \\
\hline Percentage of children attending schools with computers & $\begin{array}{c}0.6947 \\
(0.0136)\end{array}$ & $\begin{array}{c}0.5393 \\
(0.0129)\end{array}$ & $\begin{array}{l}0.1554^{*} \\
(0.0189)\end{array}$ \\
\hline Number of books per pupil & $\begin{array}{c}1.5226 \\
(0.1177)\end{array}$ & $\begin{array}{c}1.8059 \\
(0.1032)\end{array}$ & $\begin{array}{l}-0.2832 \\
(0.1566)\end{array}$ \\
\hline $\begin{array}{l}\text { Percentage of children attending schools with access to } \\
\text { internet }\end{array}$ & $\begin{array}{c}0.1088 \\
(0.0092)\end{array}$ & $\begin{array}{c}0.0457 \\
(0.0054)\end{array}$ & $\begin{array}{c}0.063^{*} \\
(0.0101)\end{array}$ \\
\hline Index of school infrastructure (out of five) & $\begin{array}{c}3.7202 \\
(0.0252)\end{array}$ & $\begin{array}{r}3.5414 \\
(0.0269) \\
\end{array}$ & $\begin{array}{l}0.1788^{*} \\
(0.0379) \\
\end{array}$ \\
\hline \multicolumn{4}{|l|}{ Teacher characteristics } \\
\hline Female teacher & $\begin{array}{c}0.6263 \\
(0.0143)\end{array}$ & $\begin{array}{c}0.5777 \\
(0.0128)\end{array}$ & $\begin{array}{l}0.0486 * \\
(0.0193)\end{array}$ \\
\hline Age of teacher (average) & $\begin{array}{c}37.5570 \\
(0.30001)\end{array}$ & $\begin{array}{l}37.2374 \\
(0.2702)\end{array}$ & $\begin{array}{c}0.3196 \\
(0.4053)\end{array}$ \\
\hline Educated to the superior level & $\begin{array}{c}0.7667 \\
(0.0125)\end{array}$ & $\begin{array}{c}0.6967 \\
(0.0119)\end{array}$ & $\begin{array}{l}0.0699 * \\
(0.0175)\end{array}$ \\
\hline Ministry of education contract & $\begin{array}{c}0.7921 \\
(0.0120)\end{array}$ & $\begin{array}{c}0.7525 \\
(0.0112)\end{array}$ & $\begin{array}{l}0.0396^{*} \\
(0.0166)\end{array}$ \\
\hline Number of training courses received by teachers (average) & $\begin{array}{c}6.6298 \\
(0.2063)\end{array}$ & $\begin{array}{c}7.4055 \\
(0.2668)\end{array}$ & $\begin{array}{c}-0.7757^{*} \\
(0.3543)\end{array}$ \\
\hline Number of cases & 1119 & 1469 & \\
\hline
\end{tabular}

Notes: Standard deviations are in parentheses. ${ }^{*}$ Significant at 1 percent level, ** significant at 5 percent level, and $* * *$ significant at 10 percent level. 
Table 3

OLS estimates of BDH on Test Scores

\begin{tabular}{|c|c|c|c|c|}
\hline Mathematics & Specification 1 & Specification 2 & Specification 3 & Specification 4 \\
\hline$T$ & $-0.507^{* *}$ & $-0.449 * * *$ & $-0.628^{*}$ & $-0.326^{* * *}$ \\
& $(0.219)$ & $(0.219)$ & $(0.213)$ & $(0.202)$ \\
$R^{2}$ & 0.021 & 0.029 & 0.111 & 0.278 \\
\hline$N$ & 2588 & 2588 & 2588 & 2588 \\
\hline Language & & & & -0.038 \\
\hline$T$ & -0.254 & -0.195 & -0.228 & $(0.184)$ \\
$R^{2}$ & $(0.198)$ & $(0.198)$ & $(0.191)$ & 0.247 \\
\hline$N$ & 0.054 & 0.06 & 0.15 & 2589 \\
\hline
\end{tabular}

Notes: Standard errors are in parentheses and corrected for heteroskedasticity. *Significant at 1 percent level, $* *$ significant at 5 percent level, and $* * *$ significant at 10 percent level.

Table 4

Participating in BDH

\begin{tabular}{|l|c|c|c|c|}
\hline \multicolumn{1}{|c|}{ Variable } & Specification 1 & Specification 2 & Specification 3 & Specification 4 \\
\hline Below cutoff point of & $0.101^{*}$ & $0.111^{*}$ & $0.093^{*}$ & $0.097^{*}$ \\
$50.65(Z)$ & $(0.042)$ & $(0.042)$ & $(0.043)$ & $(0.042)$ \\
\hline $\mathrm{R}^{2}$ & 0.113 & 0.121 & 0.138 & 0.191 \\
$N$ & 2595 & 2595 & 2595 & 2595 \\
F-statistic-of instrument & $5.79^{*}$ & $7.00^{*}$ & $4.76^{*}$ & $5.3^{*}$ \\
\hline
\end{tabular}

Notes: Standard errors in parentheses are corrected for heteroskedasticity. ${ }^{*}$ Significant at 1 percent level, ** significant at 5 percent level, and $* * *$ significant at 10 percent level.

Table 5

IV Estimates of BDH on test scores

\begin{tabular}{|c|c|c|c|c|}
\hline Mathematics & Specification 1 & Specification 2 & Specification 3 & Specification 4 \\
\hline$T$ & $\begin{array}{c}16.457^{*} \\
(8.107)\end{array}$ & $\begin{array}{c}13.710^{*} \\
(6.534)\end{array}$ & $\begin{array}{c}8.679 \\
(6.088)\end{array}$ & $\begin{array}{r}4.899 \\
(4.507)\end{array}$ \\
\hline$N$ & 2588 & 2588 & 2588 & 2588 \\
\hline \multicolumn{5}{|l|}{ Language } \\
\hline$T$ & $\begin{array}{l}10.064 * \\
(5.6953\end{array}$ & $\begin{array}{c}8.15^{*} \\
(4.675) \\
\end{array}$ & $\begin{array}{c}2.04 \\
(4.233) \\
\end{array}$ & $\begin{array}{c}0.402 \\
(3.866)\end{array}$ \\
\hline$N$ & 2589 & 2589 & 2589 & 2589 \\
\hline
\end{tabular}

Notes: Standard errors in parentheses are corrected for heteroskedasticity. $*$ Significant at 1 percent level, ** significant at 5 percent level, and $* * *$ significant at 10 percent level.

Table 6

Reduced form test score estimates

\begin{tabular}{|c|c|c|c|c|}
\hline Mathematics & Specification 1 & Specification 2 & Specification 3 & Specification 4 \\
\hline $\begin{array}{l}\text { Below cutoff point of } \\
50.65 \text { (Z) }\end{array}$ & $\begin{array}{l}1.690 * \\
(0.431)\end{array}$ & $\begin{array}{l}1.548^{*} \\
(0.432)\end{array}$ & $\begin{array}{l}0.822 * \\
(0.418)\end{array}$ & $\begin{array}{c}0.486 \\
(0.390)\end{array}$ \\
\hline$N$ & 2595 & 2495 & 2595 & 2595 \\
\hline$R^{2}$ & 0.024 & 0.032 & 0.109 & 0.277 \\
\hline \multicolumn{5}{|l|}{ Language } \\
\hline $\begin{array}{l}\text { Below cutoff point of } \\
50.65(\mathrm{Z})\end{array}$ & $\begin{array}{l}1.021 * \\
(0.392) \\
\end{array}$ & $\begin{array}{l}0.912 * \\
(0.393) \\
\end{array}$ & $\begin{array}{c}0.191 \\
(0.384) \\
\end{array}$ & $\begin{array}{r}0.039 \\
(0.371) \\
\end{array}$ \\
\hline $\begin{array}{l} \\
\mathrm{R}^{2}\end{array}$ & $\begin{array}{l}2595 \\
0.055\end{array}$ & $\begin{array}{l}2595 \\
0.061\end{array}$ & $\begin{array}{c}2595 \\
0.15\end{array}$ & $\begin{array}{l}2595 \\
0.247\end{array}$ \\
\hline
\end{tabular}

Notes: Standard errors in parentheses are corrected for heteroskedasticity. ${ }^{*}$ Significant at 1 percent level, ${ }^{* *}$ significant at 5 percent level, and ${ }^{* * *}$ significant at 10 percent level. 
Figure 1

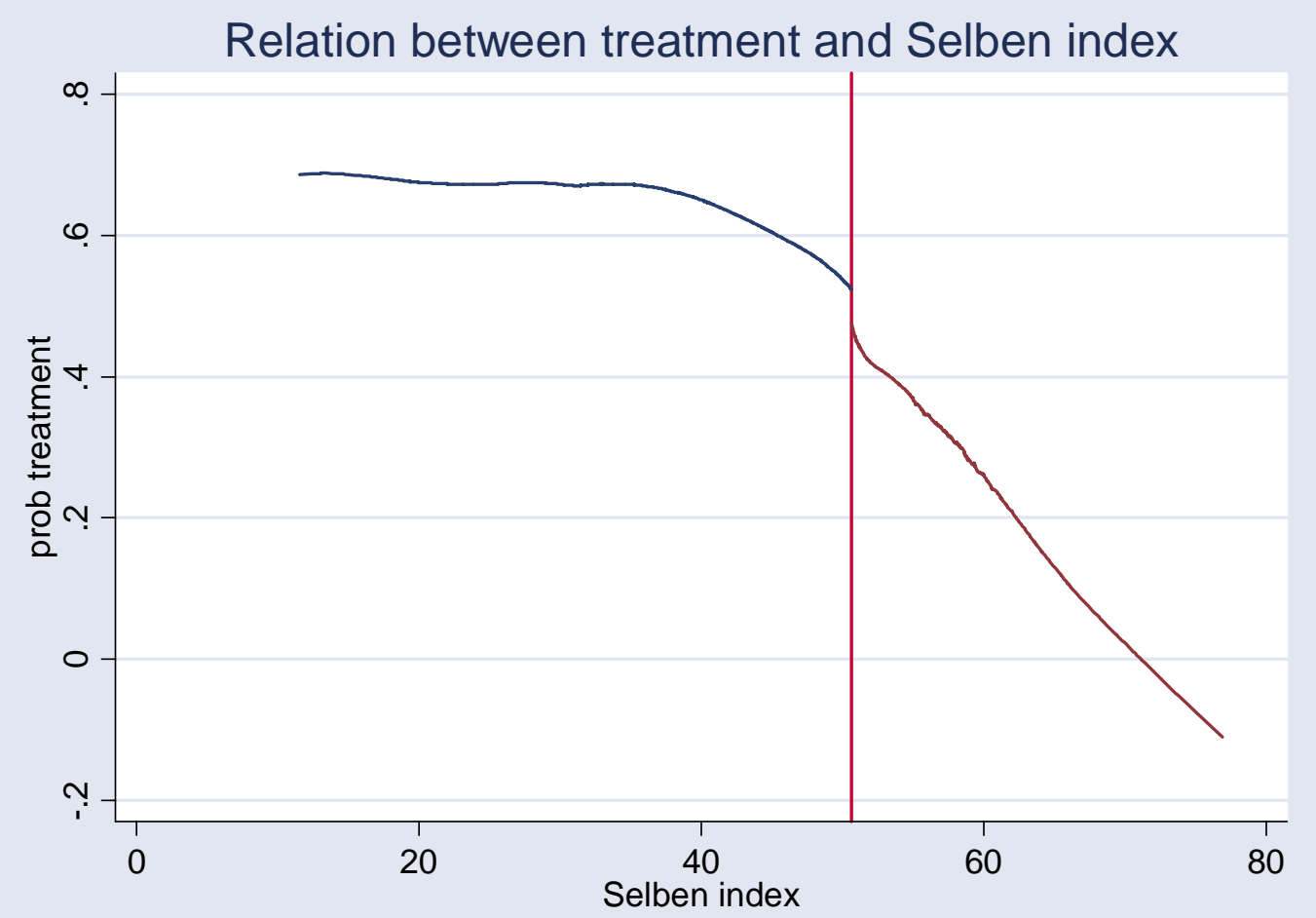


Table A1: Variables, categories and weights to construct the Selben index

\begin{tabular}{|c|c|c|c|}
\hline & & $\begin{array}{l}\text { Using } 20 \\
\text { variables } \\
\text { Weights }\end{array}$ & $\begin{array}{c}\text { Using } 27 \text { variables } \\
\text { Weights }\end{array}$ \\
\hline \multirow[t]{6}{*}{1} & Geographic area & & \\
\hline & Rural disperse-Country & 0.0000000 & 0.0000000 \\
\hline & Rural block- Coast & 1.7868746 & 1.8280949 \\
\hline & Rural block- Highlands & 1.8031189 & 1.8280949 \\
\hline & Urban-Coast & 3.1513970 & 3.2713278 \\
\hline & Urban-Highlands & 3.9311241 & 3.8165491 \\
\hline \multirow[t]{8}{*}{2} & Floor & & \\
\hline & Others & 0.0000000 & 0.0000000 \\
\hline & Soil & 0.0000000 & 0.0000000 \\
\hline & Cane & 0.0000000 & 0.0000000 \\
\hline & Plank & 1.6406758 & 1.5073765 \\
\hline & Cement & 2.7777778 & 2.6138550 \\
\hline & Tile & 5.0519818 & 4.9550994 \\
\hline & Parquet & 5.0519818 & 4.9550994 \\
\hline \multirow[t]{5}{*}{3} & Electricity & & \\
\hline & None & 0.0000000 & 0.0000000 \\
\hline & Candle & 0.4385965 & 0.4490058 \\
\hline & Private power plant & 2.9564652 & 2.9345734 \\
\hline & Public company & 6.2215724 & 6.1577935 \\
\hline \multirow[t]{4}{*}{4} & Shower availability & n.a & \\
\hline & None & & 0.0000000 \\
\hline & Shared & & 1.3113652 \\
\hline & Excusive & & 2.3537323 \\
\hline \multirow[t]{6}{*}{5} & Toilets & & \\
\hline & None & 0.0000000 & 0.0000000 \\
\hline & Latrine & 1.0883691 & 0.9300834 \\
\hline & Toilet and blind well & 1.4294997 & 1.2828736 \\
\hline & Toilet and septic well & 2.4691358 & 2.3091725 \\
\hline & Toilet and sewage systems & 4.2560104 & 4.1372675 \\
\hline \multirow[t]{5}{*}{6} & Type of cooking fuel & & \\
\hline & Others & 0.0000000 & 0.0000000 \\
\hline & Firewood & 0.0000000 & 0.0000000 \\
\hline & Electricity & 3.8661468 & 3.8325850 \\
\hline & Gas & 3.8661468 & 3.8325850 \\
\hline \multicolumn{4}{|l|}{7} \\
\hline & Land availability & n.a & \\
\hline & No & & 0.0000000 \\
\hline & Rented & & 0.7509527 \\
\hline & Own & & 2.4321901 \\
\hline \multirow[t]{4}{*}{8} & Persons per bedroom & & \\
\hline & More than 4 persons & 0.0000000 & 0.0000000 \\
\hline & Between 3 and 4 persons & 1.2345679 & 1.1866581 \\
\hline & $\begin{array}{l}\text { Up to } 2 \text { persons } \\
\text { Number of children aged under six living } \\
\text { at home }\end{array}$ & 3.6874594 & 3.6241180 \\
\hline \multirow{4}{*}{9} & Four or more children & 0.0000000 & 0.0000000 \\
\hline & 2-3 children & 2.5666017 & 3.1270045 \\
\hline & One child & 3.7037037 & 4.2655548 \\
\hline & Don't have any children & 6.3515270 & 6.8473380 \\
\hline
\end{tabular}


10 Members of working age without income

10 or more

0.0000000

0.0000000

7-9 members

0.2111761

0.6093650

5-6 members

0.9096816

1.3470173

3-4 members

1.9818064

2.4695318

1-2 members

3.9961014

4.4098781

All members receive incomes

6.0103964

6.3822963

11 Head of the home spoken language

Indigenous language

0.0000000

0.0000000

Only Spanish

0.2111761

2.4855677

Other languages

3.2488629

3.2392559

Spanish and other languages

5.0032489

4.9711353

12 Head of the home education level

None

0.0000000

0.0000000

Alphabetization Center

0.5360624

0.5131495

Basic education- adults

1.3482781

Elementary School

1.7868746

1.3149455

High school

Superior-not university

3.8174139

1.6998076

3.7203335

5.2144250

5.4743340

Superior-university

6.5951917

5.0673509

5.3720334

6.4945478

13 Spouse education level

None

Alphabetization Center

0.0000000

0.0000000

Basic education- adults

0.6172840

0.5291854

Elementary School

0.1461988

0.2245029

1.8518519

1.7639513

High school

4.1260559

4.0089801

5.1332034

5.0513149

Superior-not university

5.6042885

5.5484285

Postgraduate

6.7089019

6.8152662

Doesn't have a spouse

1.7706303

1.9082745

14 insurance

Not affiliated

0.0000000

0.0000000

3.4275504

3.3996151

15 Has the household some credit

n.a

No

Yes

16 Kitchen or kitchenette availability

No

0.0000000

5.1494477

One

6.4814815

0.0000000

2.5891056

2 o more

17 Color TV availability

No

0.0000000

2.5990903

4.4834308

0.0000000

5.0513149

6.4304041

0.0000000

2.5176395

4.4579859

2 o more

0.0000000

0.0000000

3.1676413

3.1270045

One

4.1260559

4.1051956

19 Telephone

n.a.

No

One 


\begin{tabular}{|c|c|c|c|}
\hline \multirow[t]{4}{*}{20} & Car availability & & \\
\hline & No & 0.0000000 & 0.0000000 \\
\hline & One & 4.3372320 & 4.2655548 \\
\hline & 2 o more & 5.7179987 & 5.6606799 \\
\hline \multirow[t]{4}{*}{21} & Stereo availability & & \\
\hline & No & 0.0000000 & 0.0000000 \\
\hline & One & 3.0214425 & 2.9826812 \\
\hline & 2 o more & 5.1332034 & 5.0673509 \\
\hline \multirow[t]{4}{*}{22} & VHS availability & & \\
\hline & No & 0.0000000 & 0.0000000 \\
\hline & One & 4.0935673 & 4.0410520 \\
\hline & 2 o more & 6.0103964 & 5.9493265 \\
\hline \multirow[t]{4}{*}{23} & Children aged between $6-15$ years who & to school & \\
\hline & At least one doesn't go & 0.0000000 & 0.0000000 \\
\hline & All go & 0.3573749 & 0.4008980 \\
\hline & There are no children at home & 3.5412606 & 3.5439384 \\
\hline \multirow[t]{6}{*}{24} & Type of school children attended & & \\
\hline & They don't go to school & 0.0000000 & 0.0000000 \\
\hline & All go to a public school & 0.0000000 & 0.0000000 \\
\hline & At least one goes to a public school & 0.0000000 & 0.0000000 \\
\hline & All go to a private school & 0.6335283 & 0.7055805 \\
\hline & There are no children at home & 3.3950617 & 3.3515074 \\
\hline \multirow[t]{7}{*}{25} & Number of children that have died & n.a. & \\
\hline & 4 or more & & 0.1120825 \\
\hline & Three & & 0.0000000 \\
\hline & Two & & 0.6724950 \\
\hline & One & & 1.9614436 \\
\hline & All are alive & & 4.8195472 \\
\hline & No children at home & & 7.0275723 \\
\hline \multirow[t]{4}{*}{26} & Is the last child still alive & n.a. & \\
\hline & No & & 0.0000000 \\
\hline & Yes & & 5.9515804 \\
\hline & No children at home & & 10.6926698 \\
\hline \multirow[t]{4}{*}{27} & Number of disabled persons at home & n.a. & \\
\hline & Two or more & & 0.0000000 \\
\hline & One & & 0.7509527 \\
\hline & None & & 1.5019054 \\
\hline
\end{tabular}

